\title{
Medicaid at 50 - From Welfare Program to Nation's Largest Health Insurer
}

\section{Citation}

Iglehart, John K., and Benjamin D. Sommers. 2015. "Medicaid at 50 - From Welfare Program to Nation's Largest Health Insurer." N Engl J Med 372 (22) (May 28): 2152-2159. doi:10.1056/ nejmhpr1500791.

\section{Published Version}

doi:10.1056/NEJMhpr1500791

\section{Permanent link}

http://nrs.harvard.edu/urn-3:HUL.InstRepos:16953389

\section{Terms of Use}

This article was downloaded from Harvard University's DASH repository, and is made available under the terms and conditions applicable to Other Posted Material, as set forth at http:// nrs.harvard.edu/urn-3:HUL.InstRepos:dash.current.terms-of-use\#LAA

\section{Share Your Story}

The Harvard community has made this article openly available.

Please share how this access benefits you. Submit a story.

\section{Accessibility}




\title{
H E A L T H POLICY R E PORT
}

Mary Beth Hamel, M.D., M.P.H., Editor

\section{Medicaid at 50 - From Welfare Program to Nation's Largest Health Insurer}

\author{
John K. Iglehart and Benjamin D. Sommers, M.D., Ph.D.
}

Over its 50-year history, the federal-state Medicaid program has evolved from a neglected stepchild of Medicare to the nation's largest health care program, providing coverage to tens of millions of persons and families of limited means. Withstanding perpetual challenges along a contentious political path, Medicaid expanded steadily and proved to be adaptable as demands for change arose. In the most sweeping change since the creation of the program in 1965, the Affordable Care Act (ACA) essentially completed Medicaid's transformation from a welfare-style program that served certain categories of low-income persons - namely, those with disabilities, the elderly, pregnant women, parents of dependent children, and children 18 years of age or younger - to one in which any American with a family income at or below $138 \%$ of the federal poverty level (just under $\$ 28,000$ for a family of three) is eligible to enroll. A Supreme Court ruling in 2012 effectively gave states the option of whether to expand their Medicaid programs under the ACA, and thus far, 29 states and the District of Columbia have decided to do so. ${ }^{1}$ As of December 2014, the end of the first year of the ACA expansion, 9.7 million more persons were enrolled in Medicaid and its allied program, the Children's Health Insurance Program (CHIP), than during the year before the ACA expansion went into effect. This influx of enrollees has brought the total number of beneficiaries to about 69 million, as compared with 52 million beneficiaries in Medicare as of 2012. ${ }^{2}$ Because Republicans have assumed control of the 114th Congress in Medicaid's 50th anniversary year, the program may well face new efforts to restrain its growth and grant greater flexibility to states as the GOP pursues its more conservative policy agenda.

In this article, which recognizes Medicaid's golden anniversary, we will cover key developments in the program's history and its current, if un- settled, state as the ACA is implemented, along with providing an overview of some of the most important highlights and policy debates..$^{3-9}$

\section{EARLY HISTORY AND PROGRAM}

DESIGN

Medicaid and Medicare were created as part of the Social Security Amendments of 1965, which Congress approved overwhelmingly - 307 to 116 in the House and 70 to 24 in the Senate. These programs were enacted in an era when American liberalism was at a high tide under President Lyndon B. Johnson, who launched an array of "Great Society" programs in 1964 that included a "War on Poverty." But Medicaid was essentially a creature of Congress, led by Representative Wilbur Mills (D-AR), chairman of the House Ways and Means Committee and coauthor of the earlier Kerr-Mills Act, which provided medical assistance to older persons and became a template for Medicaid. ${ }^{4}$ Wilbur Cohen, a close advisor to Mills, was also a major force in winning enactment of these programs, in part because legislators found his formula favoring incremental change more attractive than approaches to universal coverage. Cohen later became secretary of the Department of Health, Education, and Welfare, the precursor to today's Department of Health and Human Services.

Medicaid is an exemplar of federalism, a defining feature of American government in which power is shared between the federal and state governments. In the American model, ambiguity is built in because it "embodies a national-state balance in sovereignty that can be structured in different ways, at different times, by different actors, and for direct activities." Medicaid director put it, "No state has structured its program exactly like any other state. Benefits, payment rates, and eligibility have always varied, 
reflecting state-specific traditions, politics, budgets, and health care systems" (Smith V: personal communication).

At its outset, Medicaid eligibility for persons without disabilities was directly linked to the welfare system, known then as Aid to Families with Dependent Children. In the 1980s and 1990s, a series of eligibility expansions - some implemented by states at their discretion and others required by Congress - brought Medicaid coverage to broader swaths of children in low-income families, pregnant women, and parents, and the formal tie with welfare eligibility was eventually severed in 1996.10,11 Over this time, Medicaid has grown to occupy a larger percentage of state budgets, though more than half of state spending on Medicaid is reimbursed by the federal government. At Medicaid's creation in 1965, health programs received $6 \%$ of all federal grants that flowed to state and local governments. By 2010, health-related activities accounted for $58 \%$ of all federal grants-in-aid to state and local governments, with Medicaid alone spending about $95 \%$ of these health-related federal grants and squeezing competing claims for resources such as education, income security, and social services. ${ }^{5}$

Medicaid expenditures in 2014 totaled nearly $\$ 475$ billion, with the federal government contributing approximately $60 \%$ of that amount and states paying the bulk of the rest; in a few states, counties also support the program. The amount that states contribute is based on the per capita income of each state's population. The match rate (the federal share of Medicaid spending) currently ranges from a federal floor of 50\% in 13 states with the highest per capita incomes to $73.6 \%$ in Mississippi, the nation's poorest state. ${ }^{12}$ Under the ACA, the match rate for adults who are newly eligible for Medicaid is 100\% for 2014-2016 and decreases gradually to $90 \%$ in 2020 and beyond. During recessionary periods, Medicaid enrollments increase as some workers are laid off and thus lose their employer-sponsored coverage and more families meet income criteria for the program; at the same time, state budgets are typically reeling from the loss of tax revenue. Three times during recessions - in 2003, over the opposition of President George W. Bush, and again in 2009 and 2010 - Congress temporarily increased the federal share of Medicaid's costs to help alleviate this budget crunch in states.

In recent decades, as the politics surrounding federalism moved to favor greater devolution of authority to states, the federal grip on Medicaid has loosened - driven particularly by presidents who served previously as governors. Though Medicaid has always featured substantial state-level flexibility, the drumbeat in support of such efforts has intensified over time. President Ronald Reagan, a conservative Republican, was a champion of devolution but so was Bill Clinton, a moderate Democrat. In a 1993 speech, Clinton told an assembly of governors that, for many years, "governors had been screaming for relief from a cumbersome process by which the federal government had micromanaged the health care system affecting poor Americans." ${ }^{5}$ Clinton directed the Health Care Financing Administration, since renamed the Centers for Medicare and Medicaid Services (CMS), to streamline the process by which the agency considered state proposals to waive selected federal rules that states deemed too restrictive. But Clinton and his fellow Democrats drew the line when it came to accepting Republicans' favored reform of Medicaid - converting federal support to capped block grants. Research suggests that in both wealthier and poorer states, a block granting of Medicaid would require either increased state spending or reduced benefits. In one analysis, economists wrote, "We would expect a conversion to block grants to result in very substantial and widespread reductions in Medicaid benefits."

Because of the diverse and complex needs of Medicaid's population, the program covers a broad range of both health and long-term care benefits - well beyond those included in most private insurance plans. Medicaid is the primary payer for long-term services and supports (LTSS), accounting for $61 \%$ of the national spending on LTSS in 2012, which totaled $\$ 134.1$ billion. As the population ages, Medicaid's provision of LTSS is certain to increase, although currently only about half the users of these services are 65 years of age or older. In 2010, about $6 \%$ of Medicaid beneficiaries used LTSS, and total Medicaid spending on these beneficiaries accounted for almost half of all Medicaid spending. ${ }^{13}$ States also have the flexibility to cover many additional services that federal law designates as optional, such as prescription drugs, dental services, and home and community-based services. Figure 1 shows the breakdown of program expenditures, with payments to Medicaid managed-care plans, inpatient hospital care, and 


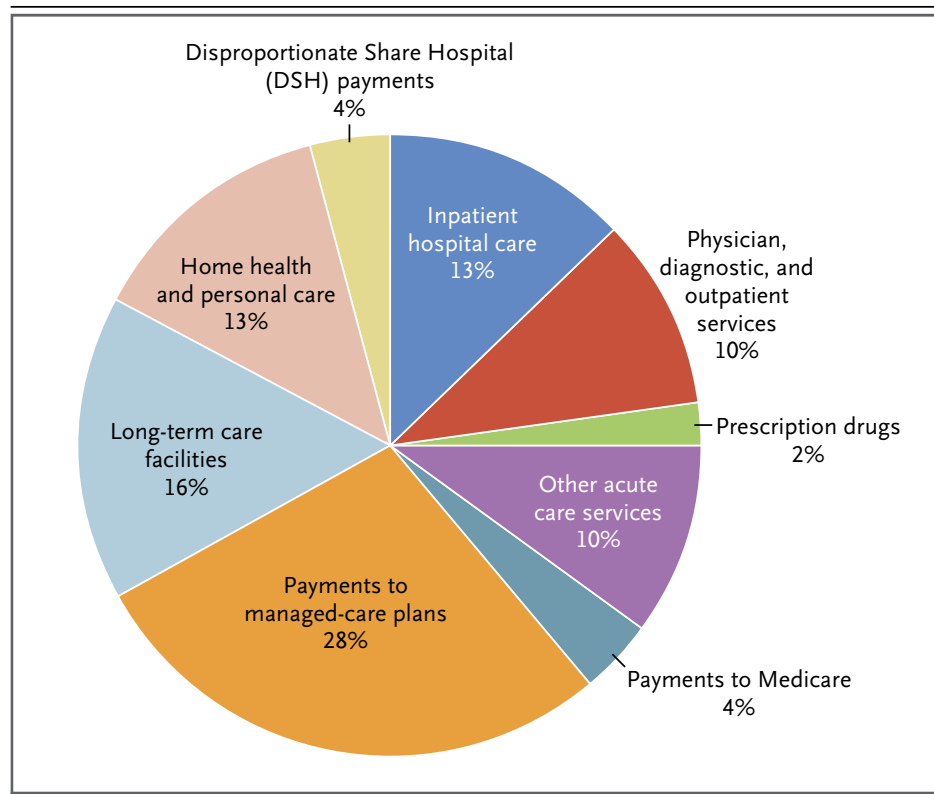

Figure 1. Share of Medicaid Expenditures in Fiscal Year 2012, According to Category.

Adapted from the Kaiser Family Foundation, "State Health Facts."

long-term institutional care making up the three largest sources of costs in Medicaid.

One of Medicaid's most widely embraced roles has been its ambitious expansion of coverage for children, a priority established by Congress that took effect in two waves - 1984-1990 and again in 1997-2009. ${ }^{4}$ In 1967, Congress also established the Early and Periodic Screening, Diagnostic, and Treatment Program, which initiated Medicaid's dual role as a financier of medical services and source of comprehensive care and prevention for America's poorest children. In the Balanced Budget Act of 1997, Congress created CHIP, which provides coverage for children in families with incomes that exceed the Medicaid eligibility threshold, with some states now covering children with family incomes as high as $300 \%$ of the federal poverty level. ${ }^{14}$

For several decades, states have been moving away from fee-for-service payment and encouraging or requiring Medicaid recipients to enroll in managed-care plans in hopes of decreasing or at least stabilizing their program costs. Under this model, states contract with managed-care plans that agree to provide all covered health care services in return for fixed (usually monthly) payments, thus making state outlays more predictable.
Although about two thirds of Medicaid beneficiaries were receiving services through managedcare plans by 2010 , less than $30 \%$ of Medicaid dollars flowed to such plans because their enrollees were typically parents and children, who are less expensive to cover than other Medicaid beneficiaries. Increasingly, states are requiring disabled and elderly beneficiaries with more expensive conditions to enroll in managed-care plans, despite the lack of experience of such plans in serving these high-risk populations. In a related development, the nation's largest private insurers are moving aggressively into the Medicaid marketplace. ${ }^{15}$ Despite the growing enthusiasm for managed care in Medicaid, evidence is mixed on whether such programs actually save money or improve the quality of care. ${ }^{16}$

\section{MEDICAID'S EFFECTIVENESS}

Following on the heels of Medicaid's rapid expansion from 1980 into the 2000s, the ACA placed the program squarely in the national spotlight as one of the law's two main approaches (along with subsidies for coverage through federal and state exchanges) to expanding health insurance coverage to millions of previously uninsured Americans. In addition to expanding eligibility dramatically, the ACA also aimed to streamline the Medicaid application process and eliminate financial asset tests for many applicants in order to improve the participation rate among eligible adults - which was roughly $60 \%$ before passage of the ACA, owing to cumbersome enrollment and renewal procedures, variable program quality, stigma, and lack of awareness. ${ }^{17-19}$

Given the dramatic increase in the number of Medicaid enrollees and the contentious divide that separates the political parties over the ACA, there has been growing interest in evaluating the program's successes and failures and how it is perceived by the public. Cross-sectional studies have noted that Medicaid beneficiaries have worse health outcomes than those with private insurance and, in some cases, than persons without any insurance. This finding has been used by some observers to make the claim that Medicaid is worse than no coverage at all, though these studies are limited in their ability to draw any true causeand-effect conclusions. ${ }^{20}$ It is simply not possible to compare beneficiaries of Medicaid - by con- 
struction, the insurer of last resort for many of society's sickest and poorest members who cannot obtain private coverage - with beneficiaries of private insurance or even patients without insurance. ${ }^{21}$

Rigorous evidence on the effects of Medicaid have come from quasi-experimental studies and the landmark Oregon Health Insurance Experiment, which was a randomized, controlled trial of Medicaid coverage on the basis of a waitinglist lottery that was conducted in Oregon in 2008. The Oregon study, which compared persons who were randomly selected to be offered Medicaid coverage with those on a waiting list who were not selected for coverage, showed convincing evidence of major improvements in the lives of low-income adults who received coverage, with better access to primary care and recommended preventive services, improved mental health, better self-reported physical health, and reduced risk of medical debt. But the Oregon researchers did not detect a statistically significant improvement in blood-pressure, cholesterol, or diabetes control during an 18-month followup period. ${ }^{22,23}$ In a larger but nonrandomized, quasi-experimental study, major Medicaid expansions in three states in the early 2000s were associated with significant gains in access to care and self-reported health and a $6 \%$ decline in mortality during a 5-year period, as compared with states not expanding Medicaid. ${ }^{24}$ These findings echo the results of previous studies on the effect of Medicaid expansions on pregnant women and children in low-income families in the 1980s and 1990s, which showed a range of health and economic benefits. ${ }^{25-28}$

Despite Medicaid's contentious political status, ${ }^{29}$ public opinion surveys find that the program is quite popular among the low-income persons who are its primary beneficiaries ${ }^{30}$ and the general public as well. One national poll showed that half of Americans had a personal connection to the program through coverage for themselves, family members, or friends, and the majority oppose any budget cuts in Medicaid to reduce the deficit. ${ }^{31}$ However, this does not mean that there is no support for reform. Although the public is generally opposed to substantial cuts in Medicaid or state block grants, the majority favor granting states more flexibility in administering their programs. ${ }^{32}$
ACA EXPANSION AND FUTURE CHALLENGES

The Supreme Court's 2012 decision changed the nature of federalism when it ruled that, unlike previous federal expansions of Medicaid, the ACA's expansion was unconstitutionally coercive toward states. The result has been a number of contentious debates carried out in state governments over whether to expand Medicaid under the health reform law. Initially, the debates followed party lines, with most states that were controlled by Democrats favoring expansion and Republican states strongly opposed because of the long-term budget implications of expansion and general opposition to the ACA. However, in recent months, the tables have turned in an increasing number of states. Republican governors in states including Indiana, Utah, Wyoming, and Tennessee have come out in support of expansion, although in the last three states, opposition from state legislators remains an obstacle. ${ }^{1}$ In Florida and Texas, two of the states with the largest numbers of uninsured Americans, most Republican leaders have remained opposed to expanding Medicaid, but hospital and private business communities are putting heavy pressure on policymakers to reconsider. ${ }^{33}$ Acknowledging the law's potential benefit to low-income Americans, Ohio's Republican Governor John Kasich surprised many conservatives with his impassioned defense of expanding Medicaid: "For those that live in the shadows of life, those who are the least among us, I will not accept the fact that the most vulnerable in our state should be ignored." 34

In some instances, Republican governors opted for expansion after negotiating program changes with Barack Obama's administration that more nearly matched their more conservative policy paths. The past 2 years have seen a proliferation of proposals for alternative approaches in Medicaid. These proposals include the so-called private option in Arkansas, in which Medicaid funds are being used to purchase private insurance for low-income adults in the ACA's insurance marketplace, ${ }^{35}$ and plans in states such as Michigan, Indiana, and Montana requiring greater use of cost-sharing, premiums, and financial incentives to promote healthy behaviors. ${ }^{36}$ Thus, although the ACA initially was 


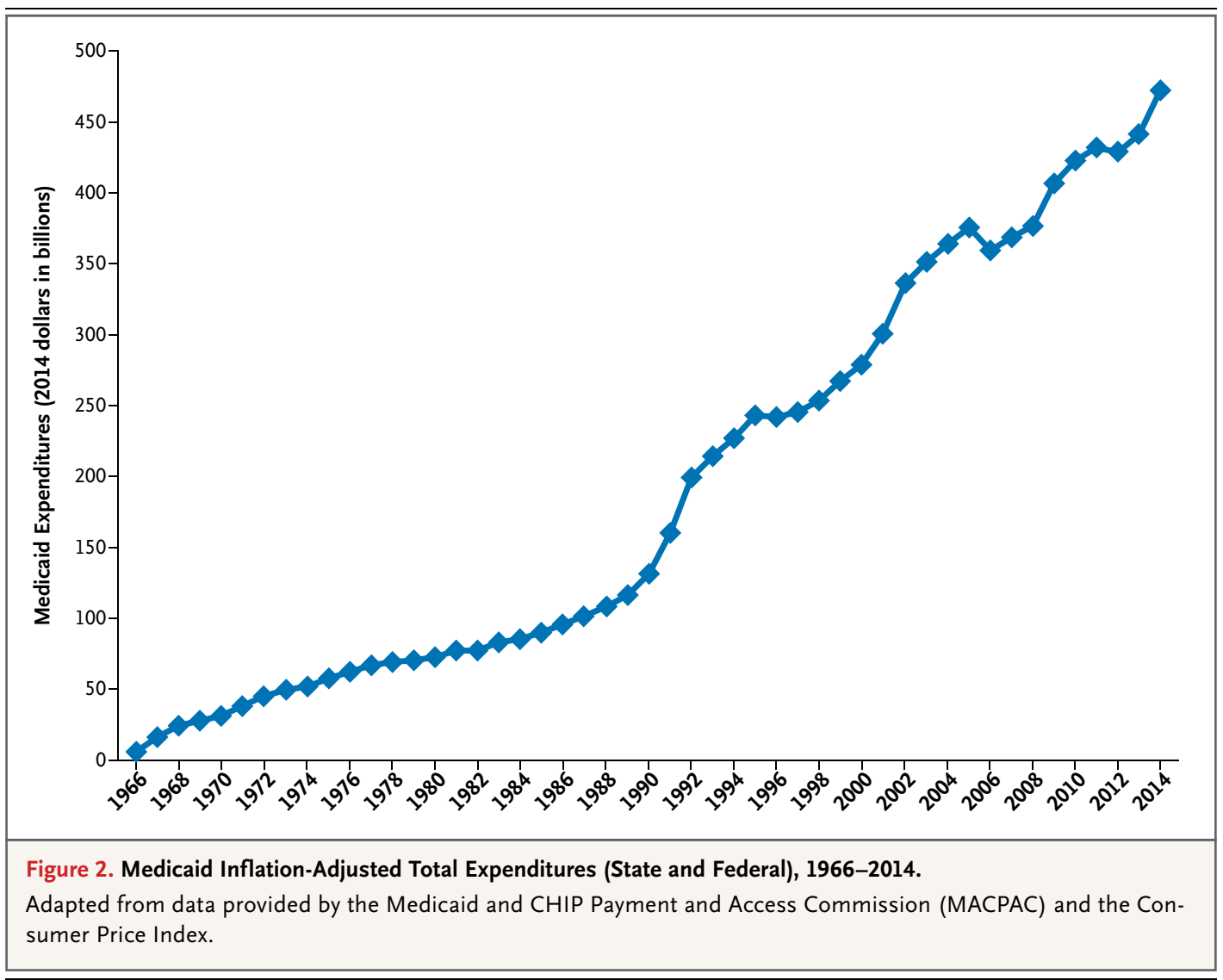

seen by many of its opponents as a centralizing force, the Supreme Court ruling has, in many ways, ushered in a new era of federalism. As Health and Human Services Secretary Sylvia Mathews Burwell stated, "We're eager and willing to work with states that have yet to expand. . . . My message to governors is, 'If you're interested in expanding, call me." 37

Beyond coverage, major concerns remain about the program's low payment rates to providers, a major driver behind the decision by some physicians not to participate in Medicaid. ${ }^{38,39}$ One recent study showed that $69 \%$ of physicians nationally are willing to accept new Medicaid patients, as compared with $82 \%$ for private insurance and $83 \%$ for Medicare. ${ }^{38}$ In the closing days of the 113th Congress, legislators potentially exacerbated the problem by not extending a 2-year increase in Medicaid fees for primary care services that had expired. The federally funded fee bump increased fees on average by $73 \%$ for services provided by family physicians, primary care internists, and pediatricians, ${ }^{40}$ and recent evidence suggests that the policy succeeded in expanding the willingness of some physicians to see new Medicaid patients. ${ }^{41}$ As of April 2015, a total of 15 states had indicated their intent to maintain higher Medicaid fees with the use of state funds, 23 states had said that they did not intend to continue the fee increase, and 13 states were undecided. ${ }^{40}$ California, which is among states paying the lowest Medicaid fees to physicians, has announced that it does not plan to raise its program's fees. In a related development, the Supreme Court recently ruled that providers do not have a legal right to sue states in federal court over Medicaid reimbursement levels, instead leaving those decisions to the Department of Health and Human Services for administrative oversight. ${ }^{42}$

Financial compensation is not the only issue. ${ }^{43,44}$ Among physicians who decline to accept Medicaid patients or limit the number they will treat, $76 \%$ cite onerous paperwork requirements and $60 \%$ cite the clinical complexity of patients enrolled in Medicaid. ${ }^{45}$ Although reducing paperwork burdens and offering more support for those 


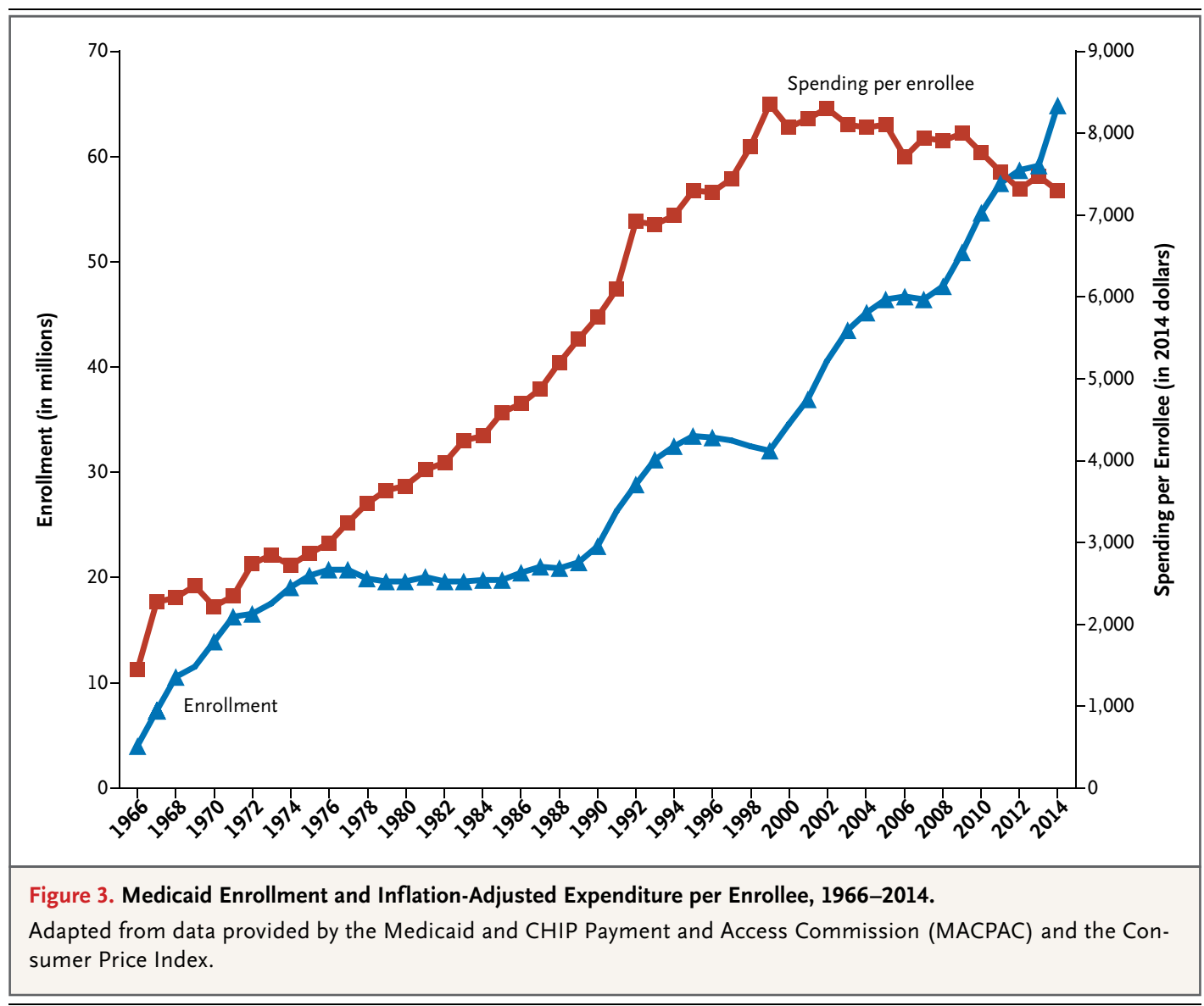

caring for patients with complex medical conditions could produce increased provider participation in the program, some observers have suggested that an ethic of professionalism alone should lead all physicians to treat at least some Medicaid patients. ${ }^{46}$ Despite the unwillingness of some providers to care for Medicaid enrollees, previous expansions have offered strong evidence that acquiring coverage through this program gives previously uninsured persons markedly enhanced access to needed medical care. ${ }^{22-24}$

The final major challenge facing the program is a budgetary one. As a former state Medicaid director put it, "The big issue for Medicaid has always been about the money. From the opening bell, governors, budget directors, and legislators have expressed concern about the long-term fiscal sustainability of Medicaid" (Smith V: personal communication). As shown in Figure 2, growth in Medicaid spending has been steep, particularly during recessions, and this growth already began to accelerate in 2014 under the
ACA. CMS is projecting that Medicaid spending will double to about $\$ 919$ billion by $2023 .{ }^{47}$ However, Figure 3 shows that this spending increase in recent years has been entirely due to increased enrollment, whereas per-enrollee spending has leveled off since 1998. In this area, there is an asymmetry between whom Medicaid covers and whom it spends its money on: although $75 \%$ of Medicaid enrollees are children and working-age adults, nearly two thirds of Medicaid dollars go toward care for the program's elderly and disabled beneficiaries. ${ }^{48}$ Key to managing Medicaid's budget pressures will be improving what is often a fragmented system of care for patients with chronic medical problems, many of whom are dually enrolled in Medicare and Medicaid or receive long-term care services. Efforts to design more coordinated care for such patients, including several state demonstration programs to improve quality and reduce the costs of care for dual-eligibles, will be central to the program's long-term financial health. ${ }^{49}$ 
As the 114th Congress takes shape and 2016 presidential contenders emerge, there are signs that some Republicans are looking for ways to "emphasize policy prescriptions to address concerns of the poor and middle class." ${ }^{50-52}$ Another political challenge that faces the new Congress is whether legislators can reduce, if not muzzle, the toxic partisanship that has greatly reduced progress in recent sessions. In announcing his retirement after 40 years, Rep. Henry A. Waxman (D-CA), one of the most successful legislators of modern times and a tenacious champion of Medicaid, emphasized that reaching out to Republicans was a key to his success. "Many times they would make criticisms or proposals that improved the legislation, and I welcomed that. . . . Every bill that I authored that became law had Republican support of one sort or another except for one, and that was the Affordable Care Act." ${ }^{3}$

Hubert Humphrey, vice president under Lyndon Johnson when Medicaid was first enacted, once said, "The moral test of government is how that government treats those who are in the dawn of life, the children; those who are in the twilight of life, the elderly; and those who are in the shadows of life, the sick, the needy, and the handicapped." Those words are inscribed on the wall of the Humphrey Building in Washington, home to the Department of Health and Human Services, which oversees Medicaid. As policymakers continue to debate the proper size, oversight, and design of the program, what is clear is that the ACA has ushered in a new era for Medicaid, in which Humphrey's "moral test" has expanded its scope far beyond the children, the elderly, and the disabled. Now at the age of 50 years, Medicaid faces a future filled with numerous challenges but also opportunities to improve health care - and health - for tens of millions of Americans.

Disclosure forms provided by the authors are available with the full text of this article at NEJM.org.

From the Department of Health Policy and Management, Harvard School of Public Health, and the Department of Medicine, Brigham and Women's Hospital - both in Boston (B.D.S.). Mr. Iglehart is a national correspondent for the Journal.

1. Kaiser Family Foundation. Status of state action on the Medicaid expansion decision. 2015 (http://kff.org/health-reform/ state-indicator/state-activity-around-expanding-medicaid-under -the-affordable-care-act).
2. Medicaid and CHIP: October 2014 monthly applications, eligibility determinations and enrollment report. Baltimore: Centers for Medicare and Medicaid Services, December 18, 2014 (http://www.medicaid.gov/medicaid-chip-program-information/ program-information/downloads/october-2014-enrollment-report .pdf).

3. Hall M, Rosenbaum S, eds. The health care "safety net" in a post-reform world. New Brunswick, NJ: Rutgers University Press, 2013.

4. Smith DG, Moore JD. Medicaid politics and policy, 19652007. New Brunswick, NJ: Transaction Publishers, 2008.

5. Thompson FJ. Medicaid politics: federalism, policy durability, and health reform. Washington, DC: Georgetown University Press, 2012.

6. Grannemann TW, Pauly MV. Medicaid everyone can count on: public choices for equity and efficiency. Washington, DC: AEI Press, 2010.

7. Engel J. Poor people's medicine: Medicaid and American charity care since 1965 . Durham, NC: Duke University Press, 2006.

8. Rowland D. Medicaid at forty. Health Care Financ Rev 20052006;27:63-77.

9. Holahan J, Weil A, Wiener JM. Federalism and health policy. Washington, DC: Urban Institute Press, 2003.

10. Kronebusch K. Medicaid for children: federal mandates, welfare reform, and policy backsliding. Health Aff (Millwood) 2001;20:97-111.

11. Weil A. There's something about Medicaid. Health Aff (Millwood) 2003;22:13-30.

12. Department of Health and Human Services, Office of the Assistant Secretary for Planning and Evaluation. ASPE FMAP 2015 report: federal financial participation in state assistance expenditures; federal matching shares for Medicaid, the Children's Health Insurance Program, and Aid to Needy Aged, Blind, or Disabled Persons for October 1, 2014 through September 30, 2015 (http:/l aspe.hhs.gov/health/reports/2014/FMAP2015/fmap15.cfm).

13. MACPAC. Medicaid's role in providing assistance with longterm services and supports: report to the Congress on Medicaid and CHIP. June 2014 (https://www.macpac.gov/publication/ ch-2-medicaids-role-in-providing-assistance-with-long-term -services-and-supports).

14. Heberlein M, Brooks T, Alker J, Artiga S, Stephens J. Getting into gear for 2014: findings from a 50-state survey of eligibility, enrollment, renewal, and cost-sharing policies in Medicaid and CHIP, 2012-2013. Washington, DC: Kaiser Family Foundation, January2013 (http://kff.org/medicaid/report/getting-into-gear-for -2014-findings-from-a-50-state-survey-of-eligibility-enrollment -renewal-and-cost-sharing-policies-in-medicaid-and-chip-2012 $-2013)$.

15. Abelson R, de la Merced MJ. WellPoint to acquire Amerigroup amid health care overhaul. New York Times. July 9, 2012 (http://dealbook.nytimes.com/2012/07/09/wellpoint-to-buy -amerigroup-for-4-9-billion/?_r=0).

16. Goodell S, Sparer M. Medicaid managed care: costs, access, and quality of care. Princeton, NJ: Robert Wood Johnson Foundation, 2012 (http://www.rwjf.org/content/dam/farm/reports/ reports/2012/rwjf401106/subassets/rwjf401106_1).

17. Sommers BD, Epstein AM. Medicaid expansion - the soft underbelly of health care reform? N Engl J Med 2010;363:2085-7. 18. Kenney GM, Lynch V, Haley J, Huntress M. Variation in Medicaid eligibility and participation among adults: implications for the Affordable Care Act. Inquiry 2012;49:231-53.

19. Allen $\mathrm{H}$, Wright BJ, Harding $\mathrm{K}$, Broffman L. The role of stigma in access to health care for the poor. Milbank Q 2014;92: 289-318.

20. Roy A. How Medicaid fails the poor. Jackson, TN: Encounter Books, 2013. 
21. Frakt A, Carroll AE, Pollack HA, Reinhardt U. Our flawed but beneficial Medicaid program. N Engl J Med 2011;364(16):e31. 22. Finkelstein A, Taubman S, Wright BJ, et al. The Oregon health insurance experiment: evidence from the first year. Q J Econ 2012;127:1057-106.

23. Baicker K, Taubman SL, Allen HL, et al. The Oregon experiment - effects of Medicaid on clinical outcomes. N Engl J Med 2013;368:1713-22.

24. Sommers BD, Baicker K, Epstein AM. Mortality and access to care among adults after state Medicaid expansions. N Engl J Med 2012;367:1025-34.

25. Currie J, Gruber J. Health insurance eligibility, utilization of medical care and child health. Q J Econ 1996;111:431-66.

26. Currie J, Gruber J. Saving babies: the efficacy and cost of recent expansions of Medicaid eligibility for pregnant women. J Polit Econ 1996;104:1263-96.

27. Cohodes S, Grossman D, Kleiner S, Lovenheim MF. The effect of child health insurance access on schooling: evidence from public insurance expansions. Cambridge, MA: National Bureau of Economics Research, 2014.

28. Levine PB, Schanzenbach DW. The impact of children's health insurance expansions on educational outcomes. Forum for Health Economics and Policy 2009;12:Article 1.

29. Iglehart JK. Medicaid revisited - skirmishes over a vast public enterprise. N Engl J Med 2007;356:734-40.

30. Epstein AM, Sommers BD, Kuznetsov Y, Blendon RJ. Lowincome residents in three states view Medicaid as equal to or better than private coverage, support expansion. Health Aff (Millwood) 2014;33:2041-7.

31. Kaiser Family Foundation. Public opinion on health care issues. May 2011 (http://kaiserfamilyfoundation.files.wordpress .com/2013/01/8190-f.pdf).

32. Evans M. Majority of voters want state autonomy for Medicaid programs. Morning Consult. November 11, 2014 (http:// morningconsult.com/2014/11/medicaid-polling).

33. Goodnough A. Health-law suit hints at G.O.P. divide. New York Times. January 11, 2015:A16 (http://www.nytimes.com/ 2015/01/11/us/health-law-suit-hints-at-gop-divide.html).

34. Hart J. John Kasich, compassionate conservative? Media Trackers. February 21, 2013 (http://mediatrackers.org/ohio/ 2013/02/21/john-kasich-compassionate-conservative).

35. Rosenbaum S, Sommers BD. Using Medicaid to buy private health insurance - the great new experiment? $\mathrm{N}$ Engl J Med 2013;369:7-9.

36. Saloner B, Sabik L, Sommers BD. Pinching the poor? Medicaid cost sharing under the ACA. N Engl J Med 2014;370:1177-80. 37. Viebeck E. Health chief 'eager' to expand ObamaCare with new governors. The Hill. November 4, 2014 (http://thehill.com/ policy/healthcare/222770-on-election-day-burwell-pushes -medicaid-expansion).

38. Decker SL. In 2011 nearly one-third of physicians said they would not accept new Medicaid patients, but rising fees may help. Health Aff (Millwood) 2012;31:1673-9.
39. Rhodes KV, Kenney GM, Friedman AB, et al. Primary care access for new patients on the eve of health care reform. JAMA Intern Med 2014;174:861-9.

40. At least 15 states will continue bump in Medicaid pay for primary care. Washington, DC: The Advisory Board, April 23, 2015 (http://www.advisory.com/daily-briefing/2015/04/23/states -to-continue-medicaid-pay-bump).

41. Polsky D, Richards M, Basseyn S, et al. Appointment availability after increases in Medicaid payments for primary care. N Engl J Med 2015;372:537-45.

42. Crane TS. Divided Supreme Court restricts provider challenges to state Medicaid rates. Health Law \& Policy Matters. April 2, 2015 (http://www.healthlawpolicymatters.com/2015/04/ 02/divided-supreme-court-restricts-provider-challenges-to -state-medicaid-rates).

43. Long SK. Physicians may need more than higher reimbursements to expand Medicaid participation: findings from Washington State. Health Aff (Millwood) 2013;32:1560-7.

44. Cunningham PJ, O'Malley AS. Do reimbursement delays discourage Medicaid participation by physicians? Health Aff (Millwood) 2009;28:w17-w28.

45. Sommers AS, Paradise J, Miller C. Physician willingness and resources to serve more Medicaid patients: perspectives from primary care physicians. Medicare Medicaid Res Rev 2011;1:1. 46. Casalino LP. Professionalism and caring for Medicaid patients — the 5\% commitment? N Engl J Med 2013;369:1775-7.

47. Radnofsky L. How health law's Medicaid enrollees strain the system. Wall Street Journal. November 13, 2014 (http://www.wsj .com/articles/how-health-laws-medicaid-enrollees-strain-the -system-1415935981).

48. Kaiser Family Foundation. The Medicaid program at a glance. 2010 (https://reachhealth.org/wp-content/uploads/2010/ 09/7235-04.pdf).

49. Cassidy A. Care for dual eligibles. Health Affairs. June 13, 2012 (http://www.healthaffairs.org/healthpolicybriefs/brief .php?brief_id=70).

50. O'Connor P. GOP hopefuls' 2016 theme has a new pitch. Wall Street Journal. January 11, 2015 (http://www.wsj.com/ articles/gop-hopefuls-2016-theme-has-a-new-pitch-1421021460). 51. Rucker P, Balz D. Economic mobility a watchword for 2016. Washington Post. January 12, 2015 (http://www.highbeam.com/ doc/1P2-37565034.html).

52. Robertson C. G.O.P. governors face test in shift on ideological agendas. New York Times. January 11, 2015 (http://www .nytimes.com/2015/01/12/us/politics/shifting-tone-republican -governors-will-face-a-test.html).

53. Hulse C, Pear R. Departing lawmakers bemoan the decline of compromise. New York Times. January 3, 2015:A12 (http:/l www.nytimes.com/2015/01/03/us/politics/departing-lawmakers -lament-capitols-partisanship.html).

DOI: 10.1056/NEJMhpr1500791

Copyright @ 2015 Massachusetts Medical Society. 